\title{
Effect of Storage on the Quality of Sachet-Vended Water in the Tamale Metropolis, Ghana
}

\author{
Abudu Ballu Duwiejuah ${ }^{1 *}$, Samuel Jerry Cobbina ${ }^{1}$, Mark Osa Akrong ${ }^{2}$ \\ ${ }^{1}$ Department of Ecotourism \& Environmental Management, Faculty of Renewable Natural Resources, University for Development \\ Studies, Tamale, Ghana; ${ }^{2}$ Environmental Biology \& Health Division, CSIR Water Research Institute, Accra, Ghana. \\ Email: ${ }^{*}$ abalu096@gmail.com, cobbinasamuel@yahoo.com
}

Received April 14 ${ }^{\text {th }}, 2013$; revised May 16 ${ }^{\text {th }}, 2013$; accepted June $13^{\text {th }}, 2013$

Copyright (C) 2013 Abudu Ballu Duwiejuah et al. This is an open access article distributed under the Creative Commons Attribution License, which permits unrestricted use, distribution, and reproduction in any medium, provided the original work is properly cited.

\begin{abstract}
Sachet water was introduced in Ghana to provide safe, hygienic and affordable instant drinking water to the general public. The aim of the study was to examine the effect of storage on the quality of sachet-vended water produced in the Tamale Metropolis. Two brands of sachet water were sampled freshly after production (Six packs or bags), transported to the laboratory and analysed. Samples of freshly prepared sachet water were then stored at ambient room temperature $\left(\right.$ at $27^{\circ} \mathrm{C}$ ), in a refrigerator $\left(\right.$ at $4^{\circ} \mathrm{C}$ ) and in the sun $\left(\right.$ at $\left.40^{\circ} \mathrm{C}\right)$. Samples from these three storage methods were collected and analysed on a weekly and monthly basis for a period of three months. The physico-chemical parameters were within World Health Organization limits regardless of the mode of storage. The $\mathrm{pH}$ of sachet water ranged from 6.69 to 7.89 with a mean of $7.38 \pm 0.31$. There was no significant difference $(p>0.05)$ in the physico-chemical parameters for the sachet water under the different storage conditions over the period. The concern however was the low concentration of these major ions, sodium, potassium, total hardness, calcium and magnesium which seem to pose direct health concerns. The counts of total heterotrophic bacteria ranged from 0.0 to $73 \mathrm{cfu} / 1 \mathrm{ml}$ with a mean of $19.16(\mathrm{SD}=21.61)$ of the sachet water samples. Total heterotrophic bacteria regrowth was observed on the third week in all brands stored and gradually deceased numerically throughout the study period. Total coliform regrowth ranged from 0.0 to $5 \mathrm{cfu} / 100 \mathrm{ml}$. There was significant difference $(\mathrm{p}<0.05)$ in total coliform counts for sachet water stored under refrigeration and in the sun. The observed regrowth and none or low microbial counts can be attributed to multiple factors such as the effect of temperature, low concentration of nutrients in sachet water, exposure to ultraviolet light rays and permeability of polythene sachet to gases such as carbon dioxide, oxygen and water vapour. Based on the findings of this study, it is recommended that Food and Drugs Authority and Ghana standard Board should ensure minerals concentrations of sachet water are improved to meet the general dietary requirement.
\end{abstract}

Keywords: Sachet-Vended Water; Storage; Water Quality; Regrowth; Tamale Metropolis; Coliform Bacteria; Significant

\section{Introduction}

Water is the elixir of life and abounds on earth, but this vast natural resource has been depleted and turned into scarce commodity with increased usage catering to the needs of ever-expanding population. There is almost a global shortage of water and the world's most urgent and front rank problem today is supply and maintenance of clean drinking water [1]. In modern times, many developing countries have included in their national plans the supply and utilisation of safe drinking water.

Several water supply models are already established,

"Corresponding author. tested and proven effective in the developed world. Given the prevailing social and technical cost needed to revitalize or put in place functional public institutions, associated technologies and political will power, it is much undoubted that the standard industrialized world model for delivery of safe drinking water technology may not be affordable in much of the developing world in the foreseeable future [2]. Subsequently, with the renewed global commitments towards the MDGs marked for 2015, the importance of locally sourced, low-cost alternative drinking water schemes in contributing to increased sustainable access in rural and peri-urban settings of developing nations cannot be over-emphasized [3]. The intro- 
duction of sachet water in Ghana was to provide safe, hygienic and affordable instant drinking water to the public and to curb the magnitude of water related infections in the country [4].

Earlier investigations conducted on the safety of drinking water in Ghana has shown that bottled water on the Ghanaian market is of good microbiological quality while the quality of some factory bagged sachet and handfilled/hand-tied polythene-bagged drinking water was noted to be doubtful [5]. Hygiene, tastes, purity and most importantly, safety is probably amongst various reasons for sachet water consumption. Sachet water may not be entirely free of all infectious microorganisms after disinfection. The potential health implications associated with sachet water is contamination, which is a factor of the source of the water itself, treatment, packaging materials, dispensing into packaging materials and closure and transportation [6]. Total heterotrophic bacteria, according to [7], can grow to levels that may be harmful to humans under improper or prolonged storage of packaged water at favourable environmental conditions.

The microbiological quality of drinking water is a concern to consumers, water suppliers, regulators and public health authorities. The potential of drinking water to transmit microbial pathogens to great number of people causing subsequent illness is well documented in many countries at all levels of economic development [8]. The bacteriological quality of drinking water is of paramount importance and its monitoring must be given the utmost priority. This is so because intake of unwholesome water could have devastating effects on our health, as unsafe drinking water is a key determinant of many microbial diseases with serious complications in immunocompetent and immunocompromised individuals [4]. An increasing body of evidence is showing that water quality interventions have a greater impact on diarrhoea incidence than previously thought, especially when interventions are applied at the household level (or point-of-use) and combined with improved water handling and storage [9].

Human health depends on safe drinking water more than any other thing, and most of the problems in developing countries are mainly due to the lack of safe drinking water [10]. Among the indicators of the presence of disease-causing bacteria in water are the coliform group of bacteria and total heterotrophic bacteria. Occurrence of coliforms in finished water in the absence of known breaches of treatment barriers, continue to be a major problem in the drinking water industry and have emerged as a critical regulatory issue [11].

The prevalence of water related diseases in developing countries is determined by the quality of their drinking water. In Ghana, the supply of piped water is inadequate in most communities. This inadequacy is both in quantity and quality of the public water supply. This has led to a tremendously increase in the production of sachet water with over 300 registered producers and over 600 unregistered producers in Ghana and according to Food and Drugs Authority of Ghana, majority of sachet water are produced under questionable hygienic environmental conditions, without approval and does not meet standards. Regardless of all these problems associated with sachet water, it is considered wholesome for drinking purposes as compared to tap or well water [12]. Safe water is a stipulation for health and development and a basic human right, yet many people are denied and its quality is also jeopardized due to mishandle and storage. In every nook and cranny of major cities and towns in Ghana, sachet water is often stored on cages without regard the effect this practice has on the quality. The objective of this study was to examine the effect of storage on the quality of sachet-vended water stored under different conditions.

\section{Materials and Methods}

Two brands of freshly produced sachet water with Food and Drugs Authority certification were randomly sampled at the point of production in the Tamale Metropolis and sent to the laboratory for analyses. Samples of the freshly produced sachet water were then stored in a refrigerator at a constant temperature of $4^{\circ} \mathrm{C}$. Some of the sachet water samples were stored at room temperature (about $27^{\circ} \mathrm{C}$ ) and in the sun at an average temperature of about $40^{\circ} \mathrm{C}$ (Plates 1-3). Six packs (3 each from a brand) of sachet water were sampled and analysed for a period of three months. Water quality analyses of stored water were conducted using American Public Health Associa-

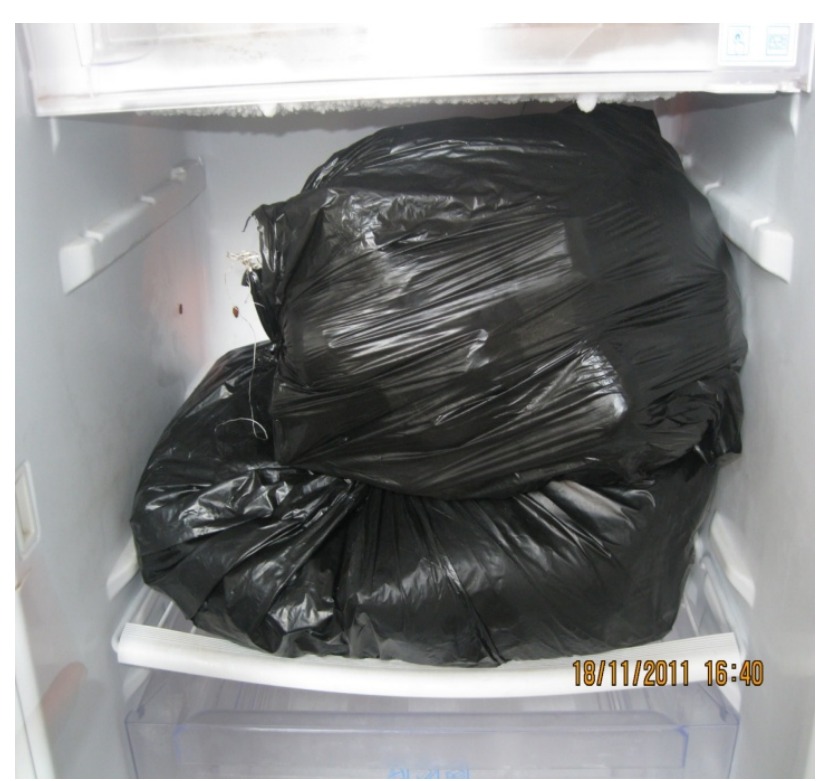

Plate 1. Sachet water stored in a refrigerator. 


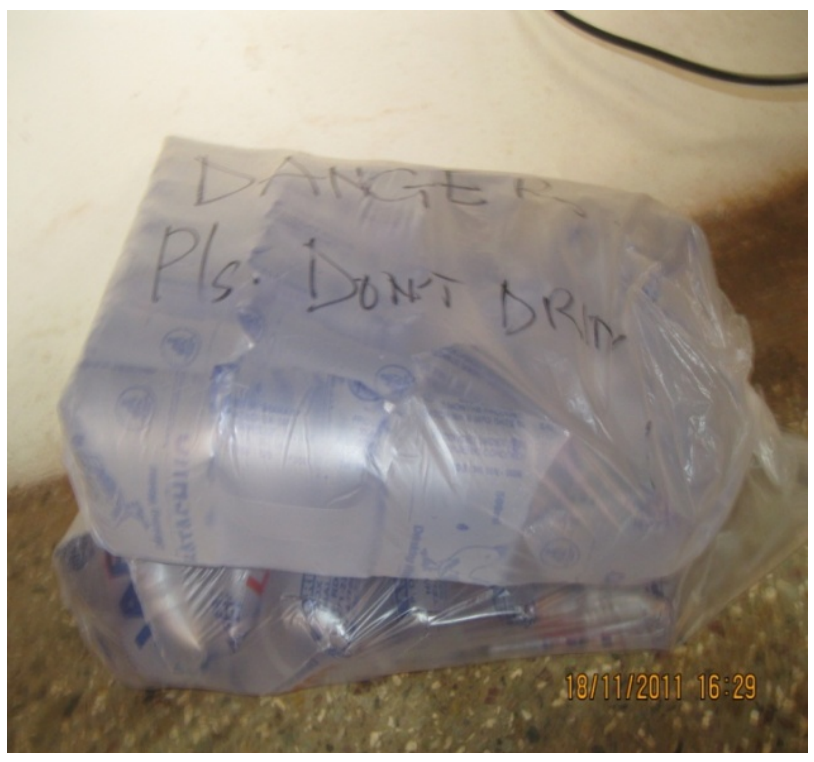

Plate 2. Sachet water stored at room temperature.

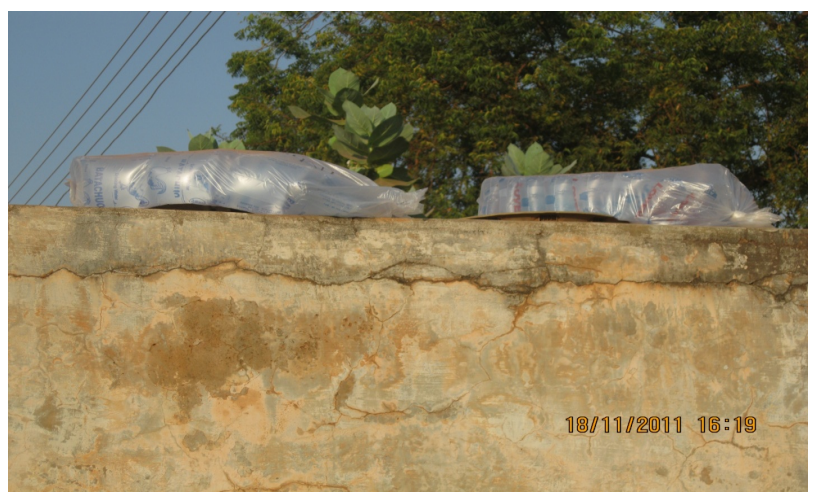

Plate 3. Sachet water stored in the sun.

tion (APHA) analytical methods [13]. Physico-chemical and bacteriological parameters of the sachet were analysed immediately after collection (Day 1). Stored sachet water samples were analysed after one week, two weeks, one month, two months and on the third month of storage. $\mathrm{pH}$, total dissolved solids and turbidity of the different sachet water were determined using a $\mathrm{pH}$-meter, electrical conductivity meter and a turbidity meter respectively. Total hardness, Total alkalinity, calcium, magnesium and chloride concentrations in the sachet water were determined using titrimetric methods.

Nutrients (such as nitrate, phosphate, fluoride and sulphate) were determined with a UV/Visible spectrophotometer in accordance with APHA 4500. Potassium and sodium were analysed with flame atomic absorption spectrophotometer (FAAS) in accordance with APHA $20^{\text {th }}$ edition 31113. Samples were analysed by direct aspiration in an air/acetylene flame at specified wavelength for both potassium and sodium. Membrane filtration technique was used to determine total and faecal coliforms,
Escherichia coli and salmonella spp in accordance with APHA 9222B, 9222D, 9260F and 9215B.

$100 \mathrm{ml}$ of each of the water samples were separately filtered through $0.45 \mu \mathrm{m}$ pore size membrane filters. Determination of Total Coliform, E. coli, Salmonella spp. and Feacal Coliform were undertaken by incubating on poured M-endo media, Hicrome (Difco) Media, SS agar and M-FC and in petri dishes at $37^{\circ} \mathrm{C} \pm 0.5^{\circ} \mathrm{C}$ and $44^{\circ} \mathrm{C}$ for 16 - 24 hours, respectively. Total Heterotrophic bacteria was determined by the pour plate method and incubated at $37^{\circ} \mathrm{C} \pm 0.5^{\circ} \mathrm{C}$ for 48 hours. Colonies were counted with a colony counter.

\section{Data Analyses}

Means, standard deviations, minimum, maximum values and multiple comparisons were calculated using SPSS (version 16.0 for Windows). One way ANOVA was used to test for significance between the modes of storage of the sachet water samples.

\section{Results and Discussion}

\subsection{Physical Examinations, Source of Water and Treatment}

The two brands met the compliance levels set by the regulatory authorities in terms of label requirements such as registration number and batch numbers, manufacturing and expiry dates, net volumes and producers' names and contact addresses. However, the nutritional information (mineral composition) was not found on the sachets of the two brands sampled for the study. It was uncovered that the two producers use tap water from the Dalun treatment plant for the production of sachet water, which is mostly the case for other producers in the metropolis. However, only the B-brand producer stores the tap water in polytanks for addition of chlorine as disinfection before using the water to produce sachet water. It was also realised that the sachet water sampled were produced under strictly hygienic conditions.

\subsection{Physico-Chemical Quality of the Sachet Water}

The $\mathrm{pH}$ of sachet water before storage was 6.69 and 6.88 for $\mathrm{B}$ and L-brands respectively and during storage $\mathrm{pH}$ values ranged from 6.69 to 7.89 with a mean of $7.38 \pm$ 0.31 (Table 1). It was observed that those stored in the sun usually record slight increase in $\mathrm{pH}$ compared with those stored at room temperature and in the refrigerator and generally $\mathrm{pH}$ increased throughout the study period. However, the difference in mode of storage was insignificant since p-values recorded were greater than 0.05 (Table 2). $\mathrm{pH}$ is one of the parameters that affect the aesthetic quality of drinking water [14]. It plays a sig- 
Table 1. Results of physico-chemical analysis of sachet water.

\begin{tabular}{|c|c|c|c|c|c|}
\hline Parameter & Min & Max & Mean & SD & Who guideline \\
\hline $\mathrm{pH}$ (pH-Units) & 6.69 & 7.89 & 7.38 & 0.31 & $6.5-8.5$ \\
\hline TDS (mg/l) & 60.1 & 114.3 & 76.33 & 14.93 & 1000 \\
\hline Total Hardness & 26 & 48 & 38.19 & 4.99 & 500 \\
\hline Calcium & 6.4 & 15.2 & 10.24 & 2.17 & 200 \\
\hline Magnesium & 0.5 & 5.3 & 2.93 & 1.28 & 150 \\
\hline Turbidity (NTU) & 1 & 7 & 2.5 & 1.3 & 5 \\
\hline Chloride & 3.97 & 9 & 6.56 & 1.12 & 250 \\
\hline Sodium & 3.9 & 8.6 & 5.67 & 1.54 & 200 \\
\hline
\end{tabular}

All other units are in mg/l except otherwise.

Table 2. Comparative analsysis of some parameters with respect to mode of storage.

\begin{tabular}{|c|c|c|c|}
\hline \multicolumn{2}{|c|}{ Mode of storage } & \multirow[t]{2}{*}{ Parameter } & \multirow{2}{*}{$\begin{array}{c}\text { Significant } \\
0.622\end{array}$} \\
\hline \multirow{2}{*}{ Refrigeration } & Room temperature & & \\
\hline & Sun & \multirow{5}{*}{$\mathrm{pH}$} & 0.402 \\
\hline \multirow{2}{*}{ Room temperature } & Refrigeration & & 0.622 \\
\hline & Sun & & 0.728 \\
\hline \multirow{2}{*}{ Sun } & Refrigeration & & 0.402 \\
\hline & Room temperature & & 0.728 \\
\hline Refrigeration & Sun & \multirow{5}{*}{$\mathrm{TH}$} & 0.857 \\
\hline \multirow{2}{*}{ Room temperature } & Refrigeration & & 0.102 \\
\hline & Sun & & 0.071 \\
\hline \multirow{2}{*}{ Sun } & Refrigeration & & 0.857 \\
\hline & Room temperature & & 0.071 \\
\hline Refrigeration & Room temperature & \multirow{5}{*}{$\mathrm{Na}$} & 0.929 \\
\hline \multirow{2}{*}{ Room temperature } & Refrigeration & & 0.929 \\
\hline & Sun & & 0.976 \\
\hline \multirow{2}{*}{ Sun } & Refrigeration & & 0.953 \\
\hline & Room temperature & & 0.976 \\
\hline \multirow{2}{*}{ Refrigeration } & Room temperature & \multirow{6}{*}{$\mathrm{K}$} & 0.451 \\
\hline & Sun & & 0.476 \\
\hline \multirow{2}{*}{ Room temperature } & Refrigeration & & 0.451 \\
\hline & Sun & & 0.966 \\
\hline \multirow{2}{*}{ Sun } & Refrigeration & & 0.476 \\
\hline & Room temperature & & 0.966 \\
\hline \multirow{2}{*}{ Refrigeration } & Room temperature & \multirow{5}{*}{$\mathrm{TC}$} & 0.096 \\
\hline & Sun & & 0.039 \\
\hline \multirow{2}{*}{ Room temperature } & Refrigeration & & 0.096 \\
\hline & Sun & & 0.672 \\
\hline Sun & Room temperature & & 0.672 \\
\hline \multirow{2}{*}{ Refrigeration } & Room temperature & \multirow{6}{*}{$\mathrm{FC}$} & 0.079 \\
\hline & Sun & & 0.079 \\
\hline \multirow{2}{*}{ Room temperature } & Refrigeration & & 0.079 \\
\hline & Sun & & 1 \\
\hline & Refrigeration & & 0.079 \\
\hline Sun & Room temperature & & 1 \\
\hline & Room temperature & & 0.845 \\
\hline Refrigeration & Sun & & 0.409 \\
\hline & Refrigeration & & 0.845 \\
\hline Room temperature & Sun & ТHB & 0.308 \\
\hline Sun & Refrigeration & & 0.409 \\
\hline sun & Room temperature & & 0.308 \\
\hline
\end{tabular}

TH: Total hardness, Na; Sodium, K; Potassium, TC; Total coliform, FC; Faecal coliform and Total Heterotrophic bacteria. 
nificant role in determining the bacterial population growth and diversity in sachet water. According to [15], microorganisms frequently change the $\mathrm{pH}$ of their own habitat by producing acidic or basic metabolic waste products.

The turbidity concentration ranged from 1 to $7.0 \mathrm{NTU}$ with a mean of $2.5 \pm 1.30$ NTU (Table 1). It was deduced that storage conditions and temperature has no effect on turbidity of sachet water. High levels of turbidity can protect microorganisms from the effect of disinfection and can stimulate bacterial regrowth [16]. Turbidity of sachet water is to confirm effectiveness or indicate problems with treatment processes particularly coagulation, sedimentation and filtration. Total Dissolved Solids concentration of sachet water before storage was $71.3 \mathrm{mg} / \mathrm{l}$ for both $\mathrm{B}$ and L-brands and during storage total dissolved solids concentration ranged from 60.1 to $114.3 \mathrm{mg} / \mathrm{l}$ with a mean of $76.33 \pm 14.93 \mathrm{mg} / \mathrm{l}$ (Table 1). It was observed that samples stored in the refrigerator recorded the lowest values as compared to those stored in the sun and at room temperature.

The concentration of total hardness of sachet water before storage was $36 \mathrm{mg} / \mathrm{l}$ and $34 \mathrm{mg} / \mathrm{l}$ for B and Lbrands respectively and during storage ranged from 26.0 to $48.0 \mathrm{mg} / \mathrm{l}$ with a mean of $38.19 \pm 4.99 \mathrm{mg} / \mathrm{l}$ (Table 1). The concentration of calcium before storage was 10.42 $\mathrm{mg} / \mathrm{l}$ and $9.62 \mathrm{mg} / \mathrm{l}$ for B and L-brands respectively and during storage ranged from 6.4 to $15.2 \mathrm{mg} / \mathrm{l}$ with a mean of $10.24 \pm 2.17 \mathrm{mg} / \mathrm{l}$ (Table 1). Magnesium concentration before storage was $2.42 \mathrm{mg} / \mathrm{l}$ for both $\mathrm{B}$ and Lbrands and during storage ranged from 0.5 to $4.6 \mathrm{mg} / \mathrm{l}$ with a mean of $2.93 \pm 1.29 \mathrm{mg} / \mathrm{l}$ (Table 1). Water has been classified on the basis of hardness as follows by WHO as follows; Soft ( 0 - $\left.50 \mathrm{mg} \mathrm{CaCO}_{3} / \mathrm{L}\right)$, Moderate Soft (50 - 100 mg $\mathrm{CaCO}_{3} / \mathrm{L}$, Slightly Hard (100 - $150 \mathrm{mg}$ $\left.\mathrm{CaCO}_{3} / \mathrm{L}\right)$, Moderate Hard (150 - $\left.200 \mathrm{mg} \mathrm{CaCO}_{3} / \mathrm{L}\right)$, Hard (200 - 300 mg $\mathrm{CaCO}_{3} / \mathrm{L}$ ) and Very Hard (over 300 mg $\mathrm{CaCO}_{3} / \mathrm{L}$ ) [17]. Moderately hard water, containing sufficient calcium is essential for normal growth and health. Moreover, hardness gives palatability to water.

Total hardness, calcium and magnesium concentrations recorded were within WHO guidelines for drinking water irrespective of their mode of storage. There was no significant difference $(p>0.05$ ) in the total hardness, calcium and magnesium for the sachet water stored under the different storage conditions (Table 2). However, the low concentrations of these minerals in sachet water have the tendency of causing health problems as the fall under the range of soft water. Reference [18] reported that soft water (that is water low in calcium and magnesium) is associated with increased morbidity and mortality from cardiovascular diseases (CVDs) compared to hard water as well as water high in magnesium. Studies also suggest that the intake of soft water, that is water low in calcium, may be associated with high risk of fracture in children
[19]. According to [20], only a few months exposure may be sufficient consumption time effects from water that is low in magnesium and/or calcium.

The concentration of chloride in sachet water before storage was $9 \mathrm{mg} / \mathrm{l}$ and $8 \mathrm{mg} / \mathrm{l}$ for B and L-brands respectively and during storage ranged from 3.97 to 9.0 $\mathrm{mg} / \mathrm{l}$ with a mean of $6.56 \pm 1.12 \mathrm{mg} / \mathrm{l}$ (Table 1). Chloride concentration of sachet water before and after storage was within WHO limit of drinking water irrespective of their mode of storage. Numerically the chloride concentration of sachet water decreased during storage. Chlorides in drinking water originate from natural sources, sewage and industrial effluents and urban runoffs. The sodium concentration of sachet water before storage was $6.3 \mathrm{mg} / \mathrm{l}$ for both brands and during storage sodium concentration ranged from 3.9 to $8.6 \mathrm{mg} / \mathrm{l}$ with a mean of $5.67 \pm 1.54 \mathrm{mg} / \mathrm{l}$ (Table 1). Sodium concentration was within WHO guidelines for drinking water and shows no significant difference $(p>0.05)$ under the different mode of storage (Table 2). However, sodium concentration in the sachet water cannot minimize the risk to hypertensive persons and heart patients. Since [21] reported that for individuals suffering from health problems such as heart disease or high blood pressure the maximum recommended sodium concentration in drinking water is 20 $\mathrm{mg} / \mathrm{l}$.

Fluoride concentration of sachet water before storage was $0.38 \mathrm{mg} / \mathrm{l}$ and $0.22 \mathrm{mg} / \mathrm{l}$ for B and L-brands respectively and during storage fluoride concentration ranged from $<0.1$ to $0.7 \mathrm{mg} / \mathrm{l}$ with a mean of $0.25 \pm 0.17 \mathrm{mg} / \mathrm{l}$. Fluoride concentration of sachet water were within WHO limit but very low in concentration (Figure 1). Phosphate concentration of sachet water before storage was $<0.001$ $\mathrm{mg} / \mathrm{l}$ for both $\mathrm{B}$ and L-brands and generally recorded a constant concentration of $<0.001 \mathrm{mg} / \mathrm{l}$ throughout the study period. Potassium concentration of sachet water before storage was $3.0 \mathrm{mg} / \mathrm{l}$ and $3.1 \mathrm{mg} / \mathrm{l}$ for B and Lbrands respectively and during storage potassium concentration ranged from 1.9 to $3.1 \mathrm{mg} / \mathrm{l}$ with a mean of $2.43 \pm 0.45 \mathrm{mg} / \mathrm{l}$ (Figure 2). It was observed that potassium concentration of sachet water decreased during storage. There was no significant difference $(p>0.05)$ in the potassium concentrations for the sachet water under the different modes of storage over the period (Table 2).

The concentration of potassium and phosphate were within the WHO limits. However, the concentrations recorded could mean that there were no microbial death and accumulation of waste. Since findings by [15] attributed the increase in phosphate and potassium concentrations in water to microbial death and accumulation of metabolic waste. The low regrowth of microbial could be attributed to low concentration of phosphate in sachet water since it is one of the limiting factors for microbial growth. It is clear that phosphate concentration of sachet 


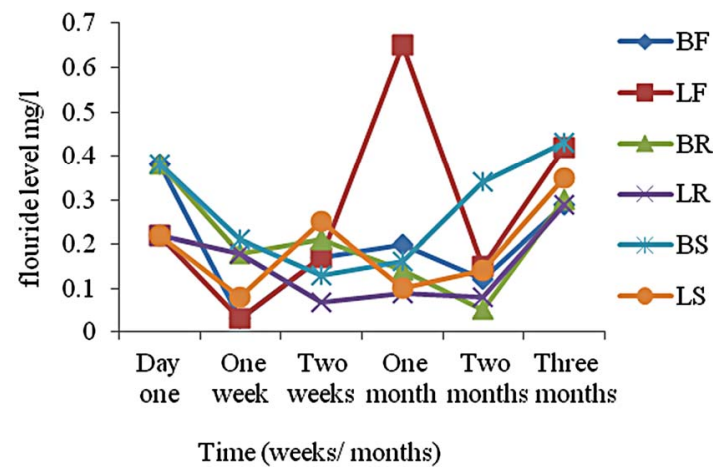

Legend BF: Batachuo Stored in Fridge, Lover Stored in Fridge, Batachuo Stored at Room Temperature, Lover Stored at Room Temperature, BS: Batachuo Stored in the Sun and Lover stored in the Sun.

Figure 1. Flouride concentration in sachet water in three months period.

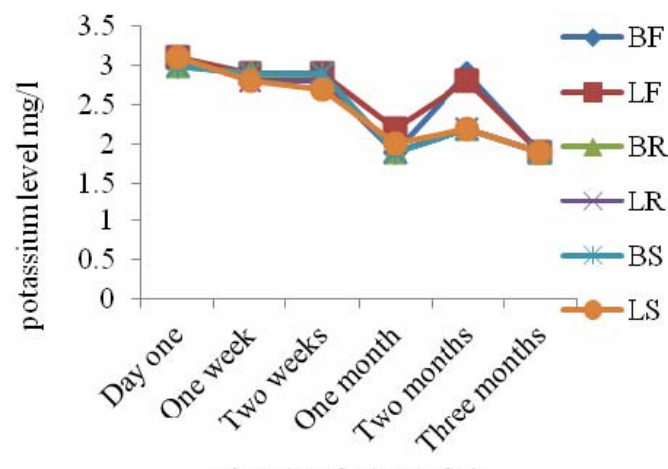

Time (weeks/ months)

Legend BF: Batachuo Stored in Fridge, Lover Stored in Fridge, Batachuo Stored at Room Temperature, Lover Stored at Room Temperature, BS: Batachuo Stored in the Sun and Lover stored in the Sun.

Figure 2. Potassium concentration of sachet water in three months period.

water may not change under any of these storage condition while decreased in potassium concentration may be due to storage effect or utilization by microorganisms for regrowth and reproduction.

The total alkalinity concentration obtained for the sachet water samples is presented in Figure 3. Total alkalinity concentration of sachet water before storage was 14 and $16 \mathrm{mg} / \mathrm{l}$ for B and L-brands respectively and during storage total alkalinity concentration ranged from 10 to $30 \mathrm{mg} / \mathrm{l}$ with a mean of $18.94 \pm 5.50 \mathrm{mg} / \mathrm{l}$. Total alkalinity concentration of sachet water increased during storage. Nitrate concentration of sachet water before storage was $2.47 \mathrm{mg} / \mathrm{l}$ and $3.07 \mathrm{mg} / \mathrm{l}$ for B and L-brands respectively and during storage nitrate concentration ranged from $<0.005$ to $3.07 \mathrm{mg} / \mathrm{l}$ with a mean of $1.64 \pm 0.77$ $\mathrm{mg} / \mathrm{l}$. It was observed that nitrate concentration of sachet water decreased during storage irrespective of mode of storage. Sulphate concentration of sachet water before storage was $20.3 \mathrm{mg} / \mathrm{l}$ and $24.4 \mathrm{mg} / \mathrm{l}$ for B and L-brands respectively and during storage sulphate concentration ranged from 6.3 to $39.06 \mathrm{mg} / \mathrm{l}$ with a mean of $22.40 \pm$ $8.75 \mathrm{mg} / \mathrm{l}$ (Figure 4).

\subsection{Bacteriological Quality}

Results of microbial quality of sachet water are presented in Figure 5. Total and faecal coliforms, Escherichia coli, salmonella spp and total heterotrophic bacteria were not detected in any of the brands before storage under the various conditions. Total coliforms counts ranged from

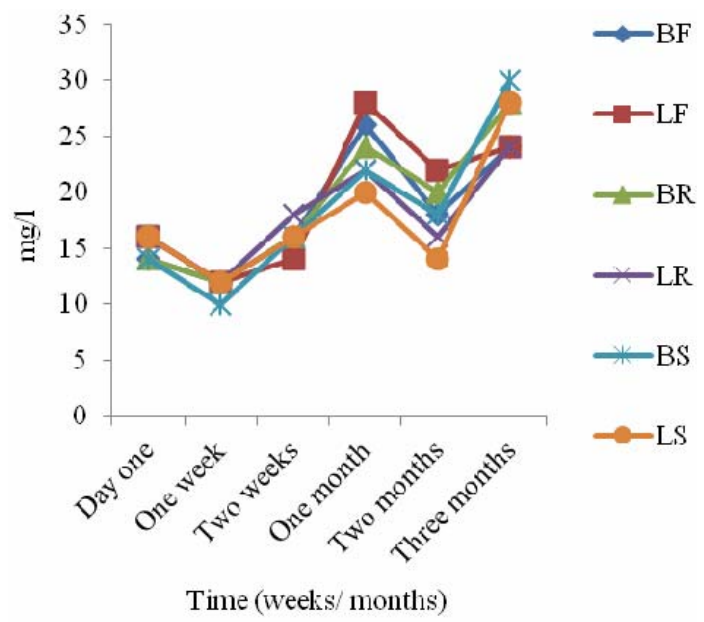

Legend BF: Batachuo Stored in Fridge, Lover Stored in Fridge, Batachuo Stored at Room Temperature, Lover Stored at Room Temperature, BS: Batachuo Stored in the Sun and Lover stored in the Sun.

Figure 3. Total alkalinity concentration of sachet water in three months period.

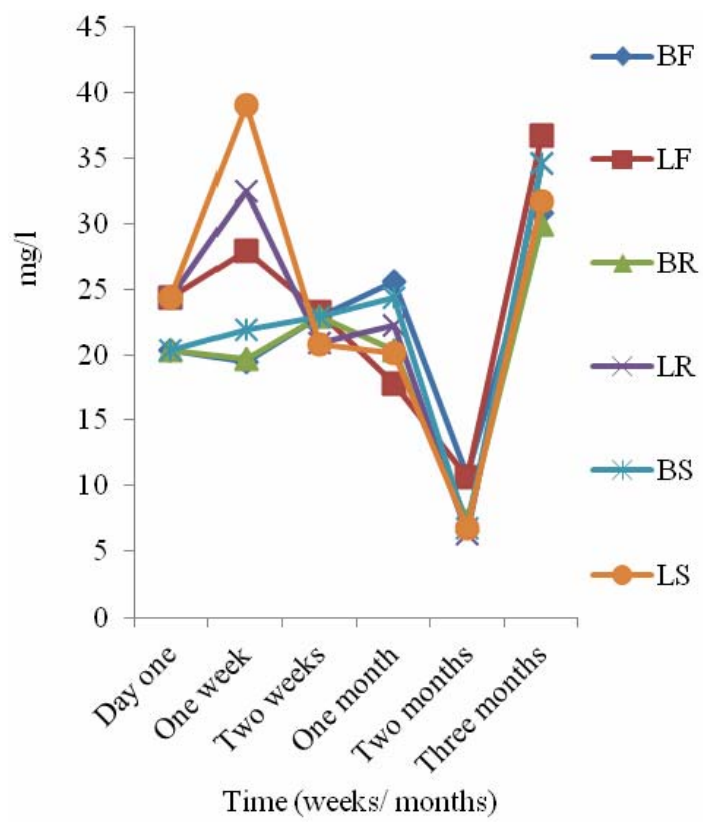

Figure 4. Sulphate concentration of sachet water in three months period. 


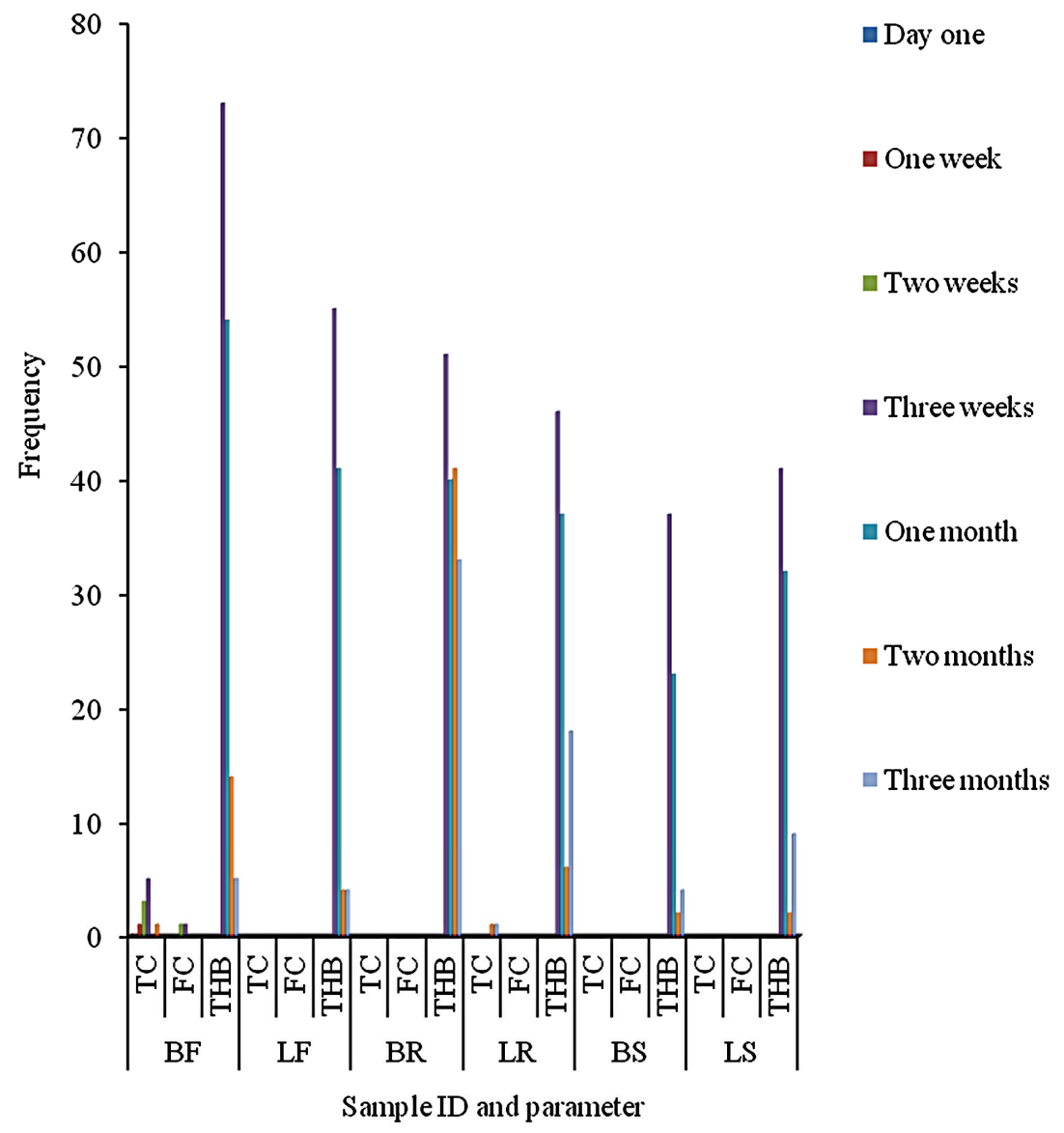

Figure 5. TC, FC and THB of sachet water in three months period.

0.0 to $5 \mathrm{cfu} / 100 \mathrm{ml}$ with a mean of $0.32(\mathrm{SD}=0.95)$ for sachet water samples stored. The maximum was recorded in samples stored in the refrigerator and only $1.0 \mathrm{cfu} / 100 \mathrm{ml}$ was detected on the second and third month for samples stored at room temperature. No total coliform was detected throughout the study period for samples stored in the sun. This finding disagrees with [22] report that storage of water at $4^{\circ} \mathrm{C}$ preserved water without microbial multiplication and at $25^{\circ} \mathrm{C}-37^{\circ} \mathrm{C}$ multiplied, but agrees with their finding that at $42^{\circ} \mathrm{C}$ most contaminants are destroyed. Perhaps the exposure of samples to ultraviolet light rays could also serve as sterilizers in samples stored in the sun and at room temperature. There was significant difference $(\mathrm{p}<0.05)$ in total coliform counts for stored sachet water under refrigeration and in the sun (Table 2). The difference between the two could be attributed to the temperature and ultraviolet light ray's effect on the coliforms. However, total coliforms regrowth during storage contradicts [23] findings that suggest that indicator organisms loose viability in freshwater environment with time. Total coliforms are widely used as indicators of the general sanitary quality of treated drinking water while faecal coliforms give a much closer indication of faecal pollution [24].
The study recorded $1.0 \mathrm{cfu} / 100 \mathrm{ml}$ of faecal coliforms for only B-brand stored in the refrigerator on the second and third week during storage. Subsequently, no regrowth of faecal coliforms for any of the brands stored under the prescribed storage conditions was detected. There was no significant difference ( $p>0.05$ ) in faecal coliform counts for sachet water stored under the different storage conditions (Table 2). The absence of faecal coliforms and the low total coliforms counts for samples stored in the sun and at room temperature may be due to temperature and the nature of packaging material used. This is in agreement with findings by [25-27], which noted that polythene sachet is more permeable to air than glass and plastic bottles. Permeability to gases such as oxygen, carbon (IV) oxide and water vapour has been reported to affect the growth and survival of microorganisms in packaged food. Escherichia coli and salmonella spp conforms to the WHO limits of zero (0) colony/100ml for drinking water. Storage conditions cannot stimulate regrowth of $E$. coli in sachet water as it has been reported that temperature and nutrient concentration are not elevated enough to support the growth of E. coli [28]. Thus, the presence of $E$. coli would have been considered as evidence of recent faecal contamination during packaging or due to 
ineffective disinfection.

The total heterotrophic counts ranged from 0.0 to 73 $\mathrm{cfu} / \mathrm{ml}$ with a mean of $19.16(\mathrm{SD}=21.61)$, the regrowth was detected for all the brands stored under various conditions on the third week of storage and gradually decreased numerically throughout the study period. Samples stored in the refrigerator recorded the highest total heterotrophic bacteria regrowth followed by those stored at room temperature and those stored in the sun recorded the lowest regrowth. However, there was no significant difference ( $p>0.05$ ) in total heterotrophic bacteria counts for sachet water under the different storage conditions (Table 2).

The total heterotrophic bacterial detected are used to determine the general microbiological quality of treated drinking water [29]. WHO drinking-water quality specifications allow total aerobic heterotrophic bacterial counts of $100 \mathrm{cfu} / \mathrm{ml}$ [29]. This limit was not exceeded by the two brands stored under the various conditions throughout the study period. The result of total heterotrophic bacteria count obtained in this study disagrees with the findings of [7]. Improper/or prolonged storage of packaged water at favourable environmental conditions, total aerobic heterotrophic bacteria can grow to levels that may be harmful to humans [7].

\section{Conclusions}

It is common to see that sachet water placed in cages in open spaces in every town or city in Ghana. For the famous reason of awareness creation for consumers who might need instant drinking water. The main objective of the study was to examine the effect of storage on the quality of sachet-vended water in Tamale Metropolis. The study revealed that most of the physico-chemical parameters were within World Health Organization limits regardless of the mode of storage. Generally there was no significant difference $(p>0.05)$ in the physico-chemical parameters for sachet water stored under the different storage conditions. The concern however was the low concentration of the major ions, sodium, potassium, total hardness, calcium and magnesium which seem to pose direct health concerns.

It is obvious that the low concentration of nutrients and factors such as temperature, ultraviolet light rays and permeability of polythene sachet to gases such as carbon dioxide, oxygen and water vapour accounted for the few or none bacteria count under the different storage conditions of the sachet water. No E. coli and salmonella spp was detected throughout the study period. Statistically there was significant difference $(p<0.05)$ in total coliform counts for stored sachet water under refrigeration and in the sun. The observed regrowth and none or low microbial counts in the stored sachet water can be attributed to multiple factors such as low nutrient concentra- tion, effect of temperature, exposure to ultraviolet light rays and permeability of polythene sachet to gases such as carbon dioxide, oxygen and water vapour.

\section{Recommendations}

Based on the findings of this study, it is recommended that Food and Drugs Authority and Ghana Standard Board should promulgate standardized method of storage of sachet water in order to increase its shelf life. The FDB and GSB should ensure minerals concentrations of sachet water are improved to meet the general dietary requirement. There is the need for regulators to ensure strict enforcement of nutritional information and the exact expiry date, which is lacking on sachet water samples.

\section{Acknowledgements}

We are grateful to the staff of the CSIR-Water Research Institute (Tamale, Ghana), especially Millicent E. AduBoakye for their support and ensuring the analysis was timely and accurate.

\section{REFERENCES}

[1] K. Agarwal and G. S. Rajwar, "Physico-Chemical and Microbiological Study of Tehri Dam Reservoir, Garhwal Himalaya,” Indian Journal of American Science, Vol. 6, No. 6, 2010, pp. 65-71.

[2] D. K. Dodoo, E. K. Quagraine, F. Okai-Sam, D. J. Kambo and J. V. Headley, "Quality of Sachet Waters in the Cape Coast Municipality of Ghana,” Journal of Environmental Science and Health, Vol. 41, No. 3, 2006, pp. 329342. doi:10.1080/10934520500423238

[3] UN Commission on Sustainable Development, "Simple Methods Lead to Dramatic Results. The Safe Drinking Water Alliance Uniting Forces to Ensure Safe Water by UN Commission on Sustainable Development," 12th Session, NewYork, 2012.

http://shopsproject.org/sites/default/files/resources/2852_f ile_safe_drinking_04_15_04.pdf

[4] G. Kwakye-Nuako, P. B. Borketey, I. Mensah-Attipoe, R. H. Asmah and P. F. Ayeh-kumi, "Sachet Drinking Water in Accra; The Potential Threats of Transmission of Enteric Pathogenic Protozoan Organisms,” Ghana Medical Journal, Vol. 41, No. 2, 2007, pp. 62-65.

[5] K. Obiri-Danso, A. Okore-Hanson, K. Jones, “The Microbiological Quality of Drinking Water Sold on the Streets in Kumasi, Ghana,” Letters in Applied Biology, Vol. 37, No. 4, 2003, p. 334.

[6] I. C. J. Omalu, G. C. Eze, I. K. Olayemi, S. Gbesi, L. A. Adeniran, A. V. Ayanwale, A. Z. Mohammed and V. Chukwuemeka, "Contamination of Sachet Water in Nigeria: Assessment and Health Impact," The Online Journal of Health and Allied Sciences, Vol. 9, No. 4, 2010, p. 15.

[7] D. W. Warburton, K. L. Dodds, R. Burke, M. A. Johnston and P. J. Laffey, "A Review of the Microbiological Quality of Bottled Water Sold in Canada between 1981 and 
1989,” Canadian Journal of Microbiology, Vol. 38, No. 1, 1992, pp. 12-19. doi:10.1139/m92-002

[8] A. Dufour, M. Snozzi, W. Koster, J. Bartram, E. Ronchi and L. Fawtrell, "Assessing Microbial Safety of Drinking Water, Improving Approaches and Methods,” WHO/OECD, 2003, p. 11.

[9] T. Clasen, W. P. Schmidt, T. Rabie, I. Roberts and S. Cairncross, "Interventions to Improve Water Quality for Preventing Diarrhoea: Systematic Review and Meta-Analysis,” British Medical Journal, Vol. 334, No. 7597, 2007, pp. 755-756. doi:10.1136/bmj.39118.489931.BE

[10] S. Parson and B. Jefferson, "Introduction to Potable Water Treatment Processes,” Blackwell Publication, Oxford, 2006. doi:10.1002/9781444305470

[11] A. K. Camper, W. L. Jones and J. T. Hayes, "Effect of Growth Conditions and Substratum Composition on the Persistence of Coli Forms in Mixed Population Biofilms,” Applied and Environmental Microbiology, Vol. 62, No. 11, 1996, pp. 4014-4018.

[12] K. K. Addo, G. L. Mensah, M. Bekoe, C. Bonsu and M. L. Akyeh, "Bacteriological Quality of Sachet Water Produced and Sold in Teshie-Nungua Suburbs of AccraGhana," American Journal of Food Agriculture Nutrition and Development, Vol. 9, No. 4, 2009, pp. 1023-1026.

[13] APHA, AWWA and WEF, "Standard Methods for the Examination of Water and Waste Water," 19th Edition, 1995, p. 1294.

[14] WHO, "Guidelines for Drinking Water Quality: Health Criteria and Other Supporting Information,” 2nd Edition, Vol. 2, 1996, World Health Organisation, Geneva.

[15] L. M. Prescott, J. P. Harley and D. A. Klein, "The Influence of Environmental Factors on Growth. Microbiology," 4th Edition, McGraw-Hill Companies, Inc., USA, 1999, pp. 123-132.

[16] WHO, “Guidelines for Drinking-Water Quality: Incorporating $1^{\text {st }}$ and $2^{\text {nd }}$ Addenda," 3rd Edition, Vol. 1, Recommendations, 2008.

[17] WHO, “Guidelines of Drinking Water Quality,” Vol. 1, Recommendations, WHO Geneva, 1984, pp. 19-115.

[18] F. Donato, S. Monarca, S. Premi and U. Gelatti, "Drinking Water Hardness and Chronic Degenerative Diseases. Part III. Tumors, Urolithiasis, Fetal Malformations, Deterioration of the Cognitive Function in the Aged and Atopic Eczema,” Annali di Igiene, Vol. 15, No. 1, 2003, pp. 57-70.

[19] V. S. Verd, S. J. Domingues, Q. M. Gonzales, M. M. Vidal, S. A. C. Mariano, C. C. de Roque and M. J. M. Sevilla,
“Association between Calcium Content of Drinking Water and Fractures in Children (in Spanish)," Anales Espanoles de Pediatria, Vol. 37, No. 6, 1992, pp. 461-465.

[20] E. Rubenowitz, I. Molin and R. Axelesson, "Magnesium Level in Drinking Water in Relation to Morbidity and Mortality from Acute Myocardial Infarction,” Epidemiology, Vol. 11, No. 4, 2000, pp. 416-421. doi:10.1097/00001648-200007000-00009

[21] T. Younos, R. Bohdan, E. Anderson, K. Ramsey, N. Cook, B. Ross and T. Dillaha, "Evaluation of Rooftop Rainfall Collection Cistern Storage Systems in Southwest Virginia,” Blacksburg, 1998, p. 23.

[22] H. Nsanze and Z. Babarinde, "Microbiological Quality of Bottled Drinking Water in the UAE and the Effect of Storage at Different Temperatures," Environmental International, Vol. 25, No. 1, 1998, pp. 53-57.

[23] WHO, "Guidelines for Drinking Water Quality: Microbiological Methods,” 2nd Edition, Vol. 1, 2001, World Health Organization, Geneva.

[24] N. J. Ashbolt, W. K. Grabow and M. Snozzi, "Indicators of Microbial Water Quality,” In: L. Fewtrell and J. Bartram, Eds., Water Quality Guidelines: Guidelines, Standards and Health, World Health Organization Water Series, IWA Publishing, London, 2001, pp. 289-315.

[25] B. J. O. Efiuvwevwere and A. E. Eka, "Shelf and Microbiological Stability of Acidified Non-Inoculated (Altenaria Tenuis) in Tomato Juice,” Journal of Food Processing and Preservation, Vol. 15, No. 3, 1991, pp. 159165. doi:10.1111/j.1745-4549.1991.tb00163.x

[26] F. A. Paine, "What Is Shelf Life?” Food Technology International Europe, 1992, p. 234.

[27] I. S. Ogiehor, E. Enaighe and G. I. Okwu, "The Effects of Different Packaging Materials and Seasonal Variations on the Quality, Changes of Tapioco (Kpokpo Gari) Produced from Cassava (Manihot esculentant crantz) during Storage,” Nigeria Annals Natural Science, Vol. 5, No. 1, 2004, pp. 16-25.

[28] E. E. Geldreich and M. Lechevallier, "Microbiological Quality Control in Distribution Systems,” In: R. D. Letterman, Ed., Water Quality and Treatment: A Handbook of Community Water Samples, 5th Edition, McGraw-Hill, New York, 1999, pp. 1-18,49.

[29] M. J. Allen, S. C. Edberg and D. J. Reasoner, "Heterotrophic Plate Count (HPC) Bacteria-What Is Their Significance in Drinking Water?” The NSF International/ WHO Symposium On HPC Bacteria in Drinking Water, Geneva, 2002, pp. 29-45. 